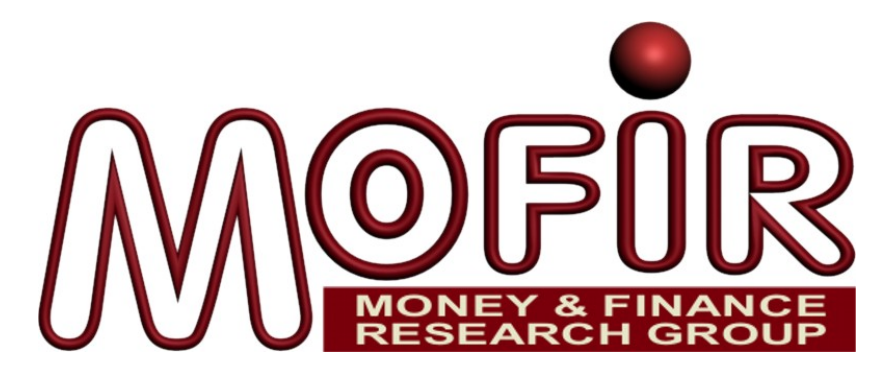

\title{
Remittances and Financial Development: Substitutes or Complements in Economic Growth?
}

\author{
Giulia Bettin \\ Hamburg Institute of International Economics (HWWI) \\ Università Politecnica delle Marche, Department of Economics \\ Alberto ZazZaro \\ Università Politecnica delle Marche, Department of Economics \\ $M o F_{I} R$ \\ CFEPSR
}

MoFiR working paper $\mathrm{n}^{\circ} 28$

September 2009 


\title{
Remittances and Financial Development: Substitutes or Complements in Economic Growth?
}

\author{
Giulia Bettin \\ Hamburg Institute of International Economics (HWWI) \\ Università Politecnica delle Marche \\ Alberto Zazzaro \\ Università Politecnica delle Marche \\ MoFir and CESPR
}

\begin{abstract}
In a recent study, Chami et al. (2003) suggested that remittances can have a negative impact on economic growth of the receiving country by diminishing the work effort of the migrants' relatives. Subsequently, Giuliano and Ruiz-Arranz (2009) found that this moral hazard effect emerges only when financial development is low. In this paper, we introduce a new indicator of financial development measuring the efficiency domestic banking system and show that the impact of remittances on economic growth is negative (positive) in countries where bank efficiency is low (high). This complementarity result is robust to controls for other financial development and institutional quality indicators.
\end{abstract}

JEL Classification: F22, F43, O16.

Keywords: migrants’ remittances, financial development, bank efficiency, economic growth.

Corresponding author: Giulia Bettin, Hamburg Institute of International Economics (HWWI), Heimhuder Strasse 71, 20148 Hamburg (Germany); e-mail: bettin@hwwi.org, g.bettin@univpm.it; tel. +49-(0)40-340576-560; fax: +49-(0)40-340576-776. We wish to thank Andrea Presbitero and Kim P. Huynh for their helpful comments. 
Migrants' remittances have grown extraordinarily over the last twenty years. According to the Migration Policy Institute, money sent home by migrants worldwide increased from US\$ 68.6 billions in 1990 to US\$ 131.5 billions in 2000 and 280.9 billions in 2006 . More than $70 \%$ of these flows goes to developing countries. Worker's remittances are now the second largest source of external finance after foreign direct investment and represent almost double the official aid to developing countries.

While there can be little doubt as to the positive effects of remittances on the standard of living for the recipient households, the macroeconomic impact of remittances is in principle ambiguous: it depends on the expenditures they fund (investment versus consumption ), the activity they stimulate (work versus leisure) and the appreciation of the real exchange rate they produce. Consistently, empirical findings on the remittances-growth nexus are mixed (Chami et al. 2003; Mundaca 2005; Catrinescu et al. 2009).

What determines a country's capacity to profit from migrants' remittances? A natural candidate to make remittances effective for growth is the level of financial development in the recipient's country. As it is well documented, access to credit is one of the major constraints for entrepreneurial activities in developing countries (Rapoport and Docquier 2005). Moreover, remittances seem to further financial development in recipients' countries which, in turn, has been shown to play a key role in reducing poverty, inequality and fostering economic growth (Aggarwal et al. 2006; Beck et al. 2007; Gupta et al. 2009). Therefore, at first sight one should expect complementarity between remittances and financial development in the growth of GDP in developing countries. Apart from removing liquidity constraints and facilitating access to credit for the migrant's relatives, remittance inflows, if efficiently intermediated, should allow the funding of growth-enhancing projects by talented but financially constrained entrepreneurs.

Surprisingly enough, however, a recent study by Giuliano and Ruiz-Arranz (2009) has provided evidence of substitutability between remittances and financial development in fostering growth. On 
analysing a set of 73 developing countries for the period 1975-2002, they found that remittance inflows are positively associated with economic growth only in countries where financial systems are not well developed. They interpret this finding in the sense that remittances compensate for inefficient credit markets, allowing recipients to accumulate financial resources to self-finance physical and human capital investments. By contrast, where credit markets work properly, access to credit is no longer an issue and remittances go to subsidize recipients' consumption and weaken incentives to work. Following this reasoning, the substitutability between remittances and financial development would come from the different uses which recipient households make of the resources transferred by migrants in different financial environments, implicitly assuming that remittances are for the most part not intermediated by banks.

Giuliano and Ruiz-Arranz (2009) measure financial development with the traditional quantitybased indicators like the ratio of liquid liabilities or credit provided by the banking sector to GDP. As remittances directly affect the magnitude of bank liquid liabilities and credit granted, the complementarity effect could simply capture a decreasing marginal impact of the size of the banking system on growth. Above and beyond, quantity-based indicators of financial development do not satisfactorily capture the bank's key functions of selecting entrepreneurs and channelling savings (remittances) towards worthy investment projects, functions that, instead, can be well approximated by quality-based indicators of the microeconomic efficiency of banks ${ }^{1}$. Obviously, the size of the domestic banking system, the whole amount of credit granted and the efficiency of local banks are not necessarily correlated. Efficient screening and monitoring of borrowers imply the rejection of all the negative net present value projects by banks, and may well be consistent with a lower credit supply.

\footnotetext{
${ }^{1}$ See Lucchetti et al. (2001); Berger et al. (2004); Hasan et al. (2007); Inklaar and Koetter (2008). In a recent study, Kessy (2008) found that the microeconomic efficiency of banks is positively correlated to economic growth of bank efficiency in the three East African countries of Kenya, Tanzania and Uganda.
} 
Using a quality-based indicator of financial development, in this paper we find support for the complementarity hypothesis and show that remittances enhance economic growth only in countries where banks are sufficiently efficient ${ }^{2}$. This result is robust to controls for quantity-based indicators of financial development and for other institutional quality indexes.

The rest of the paper is organized as follows: Section II presents the estimated models, data and variables; Section III presents descriptive evidence and econometric results; Section IV concludes.

\section{ESTIMATED MODELS AND VARIABLES}

\section{A. Models and methodology}

Following Giuliano and Ruiz-Arranz (2009), the basic model we estimate is a growth regression including the ratio of remittances to GDP, the level of financial development, an interaction term between these two variables and the set of controls described hereinafter:

$$
\begin{aligned}
& \text { GDP }_{-} \text {growth }_{i t}=\alpha_{0}+\alpha_{1} \text { GDP }_{i, t-1}+\alpha_{2} \text { REMITTANCES }_{i t}+\alpha_{3} \text { FINANCLAL DEVELOPMENT }_{i t}+ \\
& +\alpha_{4}[\text { REMITTANCES } \times \text { FINANCLAL DEVELOPMENT }]_{i t}+\sum_{j=1}^{N} \beta_{j} X_{j i t}+\tau_{t}+\varepsilon_{i t}
\end{aligned}
$$

where the sign and significance of the coefficient $\alpha_{4}$ are used to discriminate between the substitutability and complementarity hypotheses.

However, financial development and the efficiency of domestic banks could capture a more general effect of the quality of governments and institutions. This is especially true in developing countries where the degree of integrity of politicians and bureaucrats, the design of regulation and the application of the rule of law can be so poor as to make the presence of sound financial

\footnotetext{
2 The complementarity result is also found by Mundaca (2005) by using standard quantity-based indicators of financial development for countries in Central America, namely Mexico and the Dominican Republic. However, unlike Giuliano and Ruiz-Arranz (2006), her empirical strategy is simply to show that the effect of remittances on the GDP rate of growth becomes stronger when credit from domestic banks is simultaneously included in the estimated growth equation, without considering the interaction between remittances and financial development explicitly (see equation (1) below).
} 
institutions unlikely. To take these aspects into account we augment model [1] with institutional quality:

$$
\begin{aligned}
& \text { GDP }_{-} \text {growth }_{i t}=\alpha_{0}+\alpha_{1} \text { GDP }_{i, t-1}+\alpha_{2} \text { REMITTANCES }_{i t}+\alpha_{3} \text { FINANCLAL DEVELOPMENT }_{i t}+ \\
& +\alpha_{4}\left[\text { REMITTANCES } \times \text { FINANCLAL DEVELOPMENT }_{i t}+\alpha_{5} \text { INSTITUTIONAL QUALITY }_{i t}\right. \\
& +\alpha_{6}[\text { REMITTANCES } \times \text { INSTITUTIONAL QUALITY }]_{i t}+\sum_{j=1}^{N} \beta_{j} X_{j i t}+\tau_{t}+\varepsilon_{i t}
\end{aligned}
$$

Models [1] and [2] are estimated by OLS and SGMM estimators. The former method does not allow us to address the issue of the endogeneity of remittances, financial development and institutional quality to GDP growth. While growth literature has suggested many good instruments for these variables, such instruments are often time-invariant country characteristics which cannot be used in a panel framework. Moreover, economic growth is likely to be a persistent series, and a misspecification of GDP dynamics can lead to autocorrelation in the error term and biased estimates. For such reasons we estimate a dynamic panel model using the Arellano and Bover (1995) System GMM estimator, where lagged values of remittances, financial development, institutional quality, interaction terms and dependent variables act as instruments.

The sample period is 1970-2005 in model specifications with quantity-based indicators for financial development, and 1991-2005 when we consider the inefficiency of the domestic banking system. We split the sample period 1970-2005 into seven non-overlapping five-year periods and estimate model [1] using the variable mean values. With regard to the period 1991-2005, estimations are run both with five-year averages and annual data.

\section{B. Data and variables}

We consider a panel of 66 developing countries for the period $1970-2005^{3}$. The dependent variable is the growth rate of real per capita GDP in constant dollars supplied by the World Development

\footnotetext{
3 Our sample includes: Argentina, Benin, Bolivia, Botswana, Brazil, Cameroon, Chile, China, Colombia, Costa Rica, Croatia, Dominica, Dominican Rep., Ecuador, Egypt, El Salvador, Estonia, Ethiopia, Guatemala, Guyana, Haiti,
} 
Indicators database. Data on remittances come from World Bank staff estimates based on the IMF's Balance of Payments (BoP) Statistics Yearbook 2006. Remittance inflows are defined as the sum of three items: workers' remittances, compensation of non-resident employees for work performed for residents of other countries, and migrants' transfers ${ }^{4}$. As it is well known, due to the high transaction costs of using the formal banking sector, a large part of migrants' remittances go through informal channels like "hawala" or "hundi" and cannot be recorded in the BoP statistics. ${ }^{5}$ Obviously, to the extent that the non-official remittances are proportional to the official ones, the estimated effect of remittances on growth is not affected by the omission of the former. However, the informal channels for sending remittances might be more important where the deficiencies of the formal banking channel are greater. Actually, in our sample remittances are not significantly correlated with the efficiency of banks (see below Table 2) and therefore we can assume confidently that the global effect of remittances on growth is not very different from the effect found by using the official statistics on remittances.

With regard to financial development, we use two out of four traditional quantity-based indicators employed in the study by Giuliano and Ruiz-Arranz. In particular, we employ the ratio of liquid liabilities of the financial system to GDP (M2) and the ratio of domestic credit provided by the banking sector to GDP (CREDIT $)^{6}$. Data come from World Development Indicators database. In

Honduras, Hungary, India, Indonesia, Iran, Jamaica, Jordan, Kenya, Malawi, Malaysia, Mali, Malta, Mauritius, Mexico, Mozambique, Nepal, Nicaragua, Niger, Pakistan, Panama, Paraguay, Peru, Philippines, Poland, Romania, Russian Fed., Senegal, Seychelles, Sierra Leone, Slovak Rep., Slovenia, South Africa, Sri Lanka, St. Kitts and Nevis, St. Lucia, Sudan, Swaziland, Syria, Thailand, Togo, Trinidad and Tobago, Tunisia, Turkey, Uruguay, Venezuela. With respect to the study by Giuliano and Ruiz-Arranz, Barbados, Eritrea, Mauritania, Samoa, Tonga and Zimbabwe are excluded due to lack of data availability.

${ }^{4}$ Item codes in the Balance of Payments are 2391, 2310 and 2431 respectively.

5 As reported by Gupta et al. (2009), the fees paid by migrants in the United Kingdom to send remittances through formal channels may be as much as $15 \%$ of the total amount.

${ }^{6}$ We also ran regressions with the other two indicators employed by Giuliano and Ruiz-Arranz (the ratio of bank deposits to GDP and the ratio of claims on the private sector to GDP), but the estimated coefficient $\alpha_{4}$ was usually nonsignificant (results available from the authors). 
addition, we build an inefficiency index of the national banking system on the basis of the widely employed cost to income ratio ${ }^{7}$ :

$$
B A N K \text { INEFFICIENCY }{ }_{i t}=\sum_{b=1}^{B_{i}}\left(\frac{\text { Operating expenses }}{\text { Net interest revenue }+ \text { Other income }} \times 100\right)_{b t} w_{b t}
$$

where $B_{i}$ is the number of banks headquartered in country $i$ and $w_{b t}$ the market share of bank $b$ in terms of total assets. As we already stated, the microeconomic efficiency of banks captures more appropriately than $M 2$ and CREDIT the fundamental function of allocating remittances to worthy investment projects, which is crucial in terms of economic development. We use data for 53,820 banks available from the Bankscope database (Fitch-IBCA) for the period 1991-2005. Among those included in our sample, the country with the highest number of banks surveyed in Bankscope is the Russian Federation with 454 banks, while the minimum number of banks is 4 and corresponds to Guyana, Seychelles, Sierra Leone, St. Kitts and Nevis, St. Lucia and Togo. Importantly, the Bankscope database contains information on both domestic banks and subsidiaries of foreign banks, but there is nothing on either on foreign branches or on foreign bank lending in the country from abroad. However, direct lending and the activity of foreign branches usually concern large borrowers and are scarcely affected by the flow of remittances.

The set of control variables added in the estimation models [1] and [2] are the logarithm of the initial level of real per capita GDP, population growth (log difference of total population), openness to international trade (log of imports plus exports on GDP), investments (log of gross fixed capital formation on GDP), government expenditures (general government final expenditure on GDP) and inflation (annual percentage change in $\mathrm{CPI})^{8}$. All the variables are drawn from the World Development Indicators of the World Bank.

\footnotetext{
${ }^{7}$ For example, see Campa and Hernando (2006).

${ }^{8}$ With respect to the study by Giuliano and Ruiz-Arranz (2009), we excluded the years of education (which they found rarely significant) due to lack of data availability.
} 
Finally, INSTITUTIONAL QUALITY in model [2] includes indicators developed by Kaufman et al. (2006) for the pervasiveness of corruption (CONTROL OF CORRUPTION), quality of regulation (REGULATORY QUALITY), respect of law (RULE OF LAW), citizens' participation (VOICE AND ACCOUNTABILITY), political stability (POLITICAL STABILITY) and policy implementation (GOVERNMENT EFFECTIVENESS). Since these indicators are available only after 1996, we alternatively use the indexes of risk rating from the International Country Risk Guide (ICRG): ECONOMIC RISK RATING, POLITICAL RISK RATING, FINANCLAL RISK RATING and the COMPOSITE RISK INDEX which results from the synthesis of the previous ones $^{10}$. With respect to the Kaufman indicators, ICRG indicators cover a longer time span (19912004), even if they are available for only 57 of the 66 countries in our sample.

\section{EMPIRICAL ANALYSIS}

\section{A. Descriptive statistics}

Tables 1 and 2 report summary statistics and correlation for the variables of interest. Remittances on average correspond to $3.5 \%$ of GDP in our sample, but there are countries like Jordan, Haiti, El Salvador and Jamaica where they can also account for more than 15\% of GDP. The pairwise correlation between remittances and GDP growth is negative, but extremely weak and nonsignificant. As for financial indicators, what emerges is that developing countries display a great variability of financial development, especially with regard to the efficiency of the domestic banking

\footnotetext{
${ }^{9}$ CONTROL OF CORRUPTION measures people's perceptions of corruption; REGULATORY QUALITY measures the incidence of market-unfriendly regulation like price controls or inadequate bank supervision; RULE OF $L A W$ quantifies the confidence of the agents in the rules of society and in the protection of property rights; VOICE $A N D$ ACCOUNTABILITY measures the citizens' participation in politics; POLITICAL STABILITY represents the risk of sudden and violent changes in government; GOVERNMENT EFFECTIVENESS captures the ability of the government to implement good policies. All indicators vary between -2.5 and 2.5 , with higher scores corresponding to better institutions.

10 The POLITICAL RISK RATING includes 12 weighted variables covering both political and social aspects. The ECONOMIC RISK RATING includes five economic variables to assess a country's economic strength, while the aim of FINANCIAL RISK RATING is to measure a country's ability to finance its official, commercial and trade debt obligations. The Political Risk index is based on 100 points, Financial and Economic Risk on 50 points. The total points from the three indices are then weighted to produce the COMPOSITE RATE INDEX. For every index, the highest overall rating indicates the lowest risk, and the lowest rating indicates the highest risk.
} 
system (the lowest value of BANKS' INEFFICIENCY is 7.1 for Ethiopia in 2001, while the highest is 460.2 for Thailand in 2000). As expected, the efficiency of banks, M2 and CREDIT are all positively correlated to GDP growth, even if for the latter the relationship is not statistically significant. Finally, financial development indicators are positively correlated to each other, although the correlation between M2 and CREDIT is much higher than the correlation between quantity- and quality-based indicators.

[Insert Table 1 and 2]

In order to help ascertain whether financial development increases or decreases the responsiveness of growth to remittances, we plot the relationship between average remittances over the period 1970-2005 and the average growth rate of GDP, splitting the sample of developing countries according to the median value of $M 2, C R E D I T$ and BANKS' INEFFICIENCY (Figure 1). With both the traditional quantity-based indicators, a sort of substitutability relationship between remittances and financial development in fostering economic growth seems to exist. In countries with levels of M2 and CREDIT under the median, remittances and growth appear to be uncorrelated, while the relationship becomes strongly negative at high levels of financial development, especially if we exclude Jordan. When we consider the inefficiency of the domestic banking system, however, financial development and remittances seem to be complements to economic growth. When the inefficiency of local banks is low, growth and remittances are positively correlated (once again, Jordan is an outlier), while for high levels of BANKS' INEFFICIENCY the relation between growth and remittances reverses.

\section{[Insert Figure 1]}

\section{B. Regression results}

Regression results for the basic model with financial development measured by standard quantity indicators (Table 3) are only partly consistent with the findings of Giuliano and Ruiz-Arranz (2006). 
Like the latter study, we find evidence of a convergence process, a positive correlation between investments and GDP growth and a nil effect of the economy's openness. By contrast, we find that population growth and government expenditures negatively affect economic growth and that the adverse impact of inflation is only rarely significant.

Moving on to our key variables, the coefficients on REMITTANCES and FINANCLAL DEVELOPMENT are significantly positive in SGMM estimates when financial development is measured by $M 2$, while they are not significant when it is proxied by the amount of loans to the private sector $(C R E D I T)^{11}$. Whatever the measure of financial development, however, the marginal impact of remittance flows on economic growth seems to decrease when the level of financial development is higher, confirming the existence of substitutability between remittances and the aggregate quantity of finance in the country.

\section{[Insert Table 3]}

Things change when we consider the quality of domestic banks and take BANKS' INEFFICIENCY as a measure of financial development (Table 4). In this case, remittances and financial development are positively correlated with economic growth and, what is more interesting, they seem to have a complementary effect in boosting the growth of GDP. These results hold regardless of the estimation method when we use five-year data; with annual data they hold only in SGMM estimates (Table 4, columns 6).

Therefore, consistently with the information gathering and monitoring functions of banks, our findings indicate that remittances have a positive effect on economic growth only if the domestic banking system is sufficiently sound. To be precise, if we take column 6 , the value of bank inefficiency for which the remittance impact becomes zero is 52.72, while the sample mean (median) is 63.25 (61.8). This means that countries like the Russian Federation, China or Malaysia, where the

\footnotetext{
${ }^{11}$ For all the SGMM estimates reported in Tables 3-5, the result of the Hansen test of overidentifying restrictions shows that the moment conditions assumed for GMM estimation are valid. Moreover, difference-in-Hansen tests confirm that instrument subsets are exogenous.
} 
inefficiency of the domestic banking system is far below the threshold of 52.72, can benefit from remittances in terms of economic growth. By contrast, the growth of Argentina, Costa Rica or Swaziland risks being adversely affected by migrants' remittances due to the inefficiency of their banking system.

\section{[Insert Table 4]}

To test the robustness of the complementarity result, in columns $3,4,7$ and 8 we include both qualitative and quantitative financial development indicators. REMITTANCES, BANKS, INEFFICIENCY and their interaction are still significant and with the expected signs, regardless of the sample splitting, while $M 2$ and CREDIT are hardly ever significant.

Finally, Table 5 reports SGMM estimates of equation [2] with annual data. As far as the World Bank Governance Indicators are considered, CONTROL OF CORRUPTION, REGULATORY QUALITY and RULE OF LAW (column 1-3) contribute significantly to economic growth and the positive sign on the interaction term shows that the impact of remittances is stronger in the presence of sound institutions. The other three dimensions of governance seem to affect neither economic growth nor the effectiveness of remittances in boosting growth. When we include in the regression all the dimensions of governance singularly correlated to growth (column 7), only REGULATORY QUALITY maintains its significance, reinforcing the positive effect of remittances on GDP. In any case, what is important is that, after controlling for the quality of the institutional environment, the complementarity between remittances and the efficiency of domestic banks in economic growth is not rejected at a $1 \%$ level of confidence, regardless of the specification considered.

\section{[nsert Table 5]}

The last four columns of Table 5 report results of the estimates with ICRG indicators. While complementarity between finance and remittances is confirmed, the positive impact of sound 
institutions on growth and the complementarity with remittances is statistically weaker ${ }^{12}$. These results partly conflict with findings provided by Catrinescu et al. (2009) for a larger set of countries. Like us, they found no direct or indirect (via remittances) effect of the political risk composite indicator on growth. However, when they split this indicator into their components they found that many of such components, like ethnic tension or government stability, are positively associated to growth.

\section{CONCLUDING REMARKS}

In this paper we analysed the relationship between remittances and the level of financial development in economic growth. Moving on from the study by Giuliano and Ruiz-Arranz (2009), where financial development is proxied with the traditional quantity-based indicators, we introduced a new quality-based measure regarding the inefficiency of the domestic banking system. Using a panel of 66 developing countries for the period 1991-2005, we showed that an efficient banking system complements the positive effect of remittances on GDP growth. Remittance flows not only relax liquidity constraints and guarantee access to credit, but can also contribute, when mediated by an efficient banking system, to funding growth-enhancing projects. This result is robust to controls for other quantity-based measures of financial development and the quality of other institutions.

\footnotetext{
${ }^{12}$ When simply augmenting specification [1] with the institutional quality indicator, without considering the interaction term with remittances, the risk indicators are significant with the expected sign.
} 


\section{REFERENCES}

Aggarwal, R., Demirgüç-Kunt, A. and Martinez Peria, M.S. (2006). 'Do workers' remittances promote financial development?', WBPR WP No. 3957, The World Bank, Washington D.C.

Arellano, M. and Bover, O. (1995). 'Another look at the instrumental-variable estimation of errorcomponents models', Journal of Econometrics, 68, pp.29-52.

Beck, T., Demirgüç-Kunt, A. and Levine, R. (2007). 'Finance, inequality and the poor', Journal of Economic Growth, 12, pp.27-49.

Berger, A.N., Hasan, I. and Klapper, L.F. (2004). 'Further evidence on the link between finance and growth: An international analysis of community banking and economic performance', Journal of Financial Services Research, 25, pp.169-202.

Campa, J.M. and Hernando, I. (2006). 'M\&A performance in the European financial industry', Journal of Banking and Finance, 30, pp.3367-92.

Catrinescu, N., Leon-Ledesma, M., Piracha, M. and Quillin, B. (2009). 'Remittances, institutions and economic growth', World Development, 37(1), pp.81-92.

Chami, R., Fullenkamp, C. and Jahjah, S. (2003). 'Are migrant remittance flows a source of capital for development?', IMF Working Paper, International Monetary Fund, Washington D.C.

Giuliano, P. and Ruiz-Arranz, M. (2009). 'Remittances, financial development and growth', Journal of Development Economics, forthcoming.

Gupta, S., Catherine, A.P. and Wagh, S. (2009). 'Effect of Remittances on Poverty and Financial Development in sub-Saharan Africa', World Development, 37(1), pp.104-115.

Hasan, I., Kötter, M. and Wedow, M. (2007). 'The quality of banking and regional growth', Deutsche Bundesbank Discussion Paper Series 2, No. 10, Deutsche Bundesbank, Frankfurt.

Inklaar, R. and Koetter, M. (2008). 'Financial dependence and industry growth in Europe: Better banks and higher productivity', mimeo, University of Groningen.

Kaufmann, D., Kraay, A. and Mastruzzi, M. (2006). 'Governance matters V: Aggregate and individual governance indicators for 1996-2005', The World Bank, Washington D.C.

Kessy, P. J. (2008). 'Financial sector efficiency and economic growth: The case of East African Community (EAC) Countries, mimeo, Bank of Tanzania, available at http://www.csae.ox.ac.uk/conferences/2008-EdiA/papers/019-Kessy.pdf.

Lucchetti, R., Papi, L. and Zazzaro, A. (2001). 'Banks' inefficiency and economic growth: A micromacro approach', Scottish Journal of Political Economy, 48, pp.4004-24.

Mundaca, G. (2005). 'Can remittances enhance economic growth? The role of financial markets development', mimeo, University of Oslo. 
Rapoport, H. and Docquier, F. (2005). 'The economics of migrants' remittances', IZA Discussion Paper No. 1531, IZA, Bonn. 
FIGURE 1

Remittances and GDP growth rate by levels of financial development.

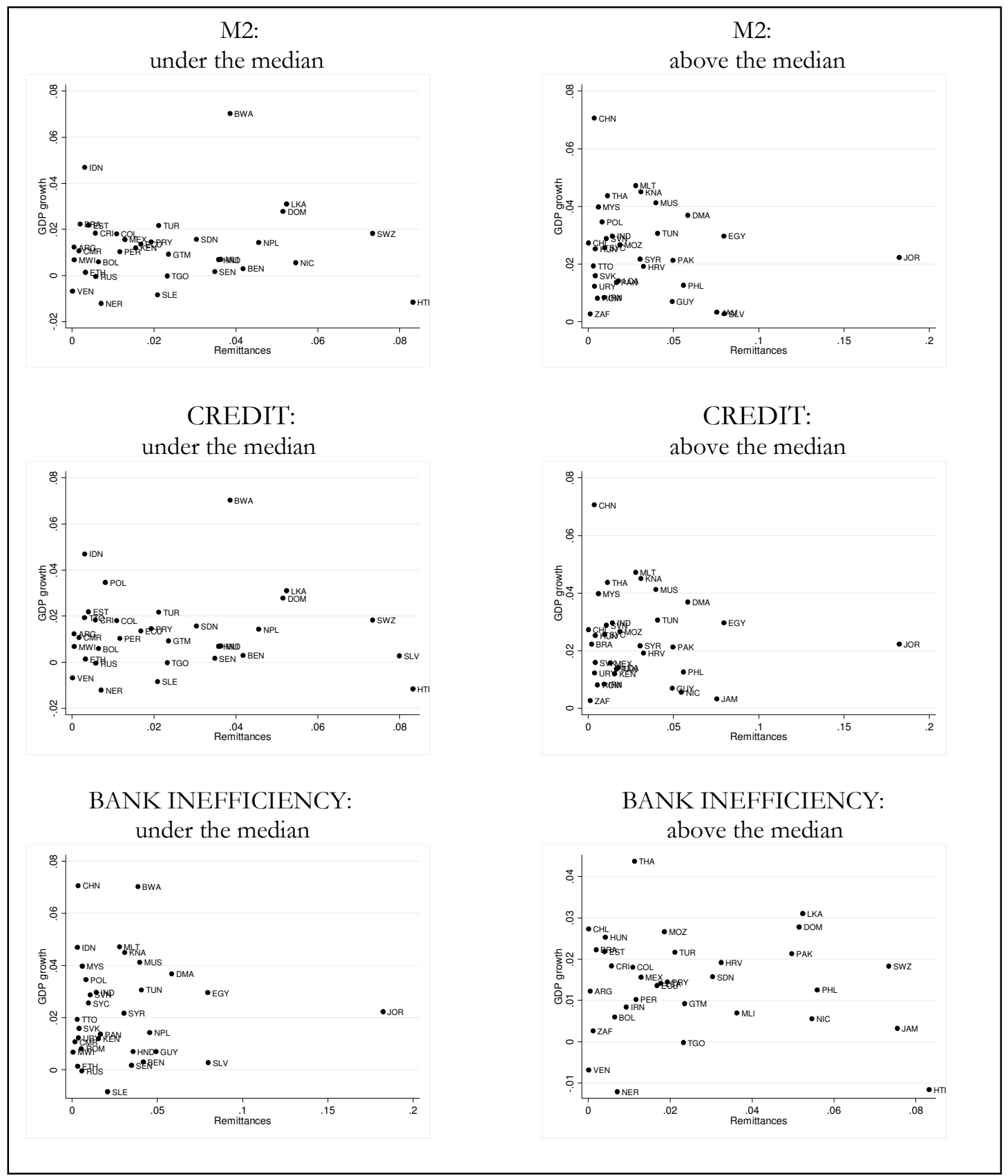

For each country, remittances and GDP growth rate are expressed as mean values over the period 1970-2005. To split the sample, we consider the median level of financial development indicators. 
TABLE 1

Summary statistics (annual data, 1991-2005)

\begin{tabular}{|l|c|c|c|c|c|c|}
\hline \multicolumn{1}{|c|}{ Variable } & Mean & Median & St. Dev. & Min. & Max. & Obs. \\
\hline GDP GROWTH & 0.023 & 0.025 & 0.034 & -0.121 & 0.147 & 618 \\
POPULATION GROWTH & 0.015 & 0.017 & 0.010 & -0.033 & 0.052 & 618 \\
INVESTMENTS & 3.045 & 3.052 & 0.281 & 1.174 & 3.992 & 618 \\
INFLATION & 9.863 & 5.965 & 15.564 & -8.238 & 154.764 & 618 \\
GOVERNMENT EXPENDITURES & 13.805 & 12.781 & 4.821 & 4.013 & 31.134 & 618 \\
OPENNESS & -0.322 & -0.345 & 0.543 & -1.777 & 0.835 & 618 \\
REMITTANCES & 0.035 & 0.015 & 0.047 & 0.000 & 0.276 & 618 \\
BANK INEFFICIENCY & 63.251 & 61.800 & 28.089 & 7.099 & 460.216 & 618 \\
M2 & 48.173 & 39.337 & 32.148 & 6.952 & 161.143 & 618 \\
CREDIT & 54.653 & 43.754 & 42.780 & -72.994 & 221.807 & 616 \\
\hline
\end{tabular}


TABLE 2

Pairwise correlations

\begin{tabular}{|l|c|c|c|c|c|}
\hline & $\begin{array}{c}\text { GDP } \\
\text { GROWTH }\end{array}$ & REMITTANCES & $\begin{array}{c}\text { BANK } \\
\text { INEFFICIENCY }\end{array}$ & M2 & CREDIT \\
\hline GDP GROWTH & 1 & 1 & & & \\
REMITTANCES & -0.059 & $-0.119^{*}$ & 0.053 & 1 & \\
BANK INEFFICIENCY & $0.069 *$ & 0.049 & $-0.144^{*}$ & 1 & \\
M2 & 0.005 & -0.033 & $-0.073^{*}$ & $0.812^{*}$ & 1 \\
CREDIT &
\end{tabular}

$*$ significant at $5 \%$. Correlations are calculated for the main variables of interest referring to annual data. 
TABLE 3

Estimations with quantity-based indicators for financial development

\begin{tabular}{|c|c|c|c|c|}
\hline \multirow{2}{*}{ Dep Var: GDP growth } & \multicolumn{2}{|c|}{ M2 } & \multicolumn{2}{|c|}{ Credit } \\
\hline & OLS & SGMM & OLS & SGMM \\
\hline$G D P_{t-1}$ & $\begin{array}{c}-0.022^{* *} \\
(0.010)\end{array}$ & $\begin{array}{c}-0.042^{* *} \\
(0.018)\end{array}$ & $\begin{array}{c}-0.020^{* *} \\
(0.010)\end{array}$ & $\begin{array}{l}-0.036 \\
0.023)\end{array}$ \\
\hline POPULATION GROWTH & $\begin{array}{c}-0.039 * * * \\
(0.011)\end{array}$ & $\begin{array}{c}-0.047 * * * \\
(0.014)\end{array}$ & $\begin{array}{c}-0.043^{* * * *} \\
(0.011)\end{array}$ & $\begin{array}{c}-0.053^{* * * *} \\
(0.015)\end{array}$ \\
\hline INVESTMENTS & $\begin{array}{c}0.201 * * * \\
(0.034)\end{array}$ & $\begin{array}{c}0.216^{* * *} \\
(0.035)\end{array}$ & $\begin{array}{c}0.221 * * * \\
(0.035)\end{array}$ & $\begin{array}{c}0.243^{* * *} \\
(0.034)\end{array}$ \\
\hline INFLATION & $\begin{array}{c}0.000 \\
(0.000)\end{array}$ & $\begin{array}{c}0.000 \\
(0.000)\end{array}$ & $\begin{array}{c}0.000 \\
(0.000)\end{array}$ & $\begin{array}{c}0.000 \\
(0.001)\end{array}$ \\
\hline GOVERNMENT & $-0.005^{* * *}$ & $-0.006 * * *$ & $-0.005^{* * *}$ & $-0.006 * * *$ \\
\hline EXPENDITURES & $(0.002)$ & $(0.002)$ & $(0.001)$ & $(0.002)$ \\
\hline OPENNESS & $\begin{array}{l}-0.001 \\
(0.019)\end{array}$ & $\begin{array}{l}-0.002 \\
(0.021)\end{array}$ & $\begin{array}{c}0.008 \\
(0.021)\end{array}$ & $\begin{array}{c}0.014 \\
(0.020)\end{array}$ \\
\hline REMITTANCES & $\begin{array}{c}0.285 \\
(0.366)\end{array}$ & $\begin{array}{c}1.028^{* *} \\
(0.508)\end{array}$ & $\begin{array}{c}0.265 \\
(0.340)\end{array}$ & $\begin{array}{c}0.720 \\
(0.463)\end{array}$ \\
\hline M2 & $\begin{array}{c}0.001 * * * \\
(0.000)\end{array}$ & $\begin{array}{c}0.002^{* * *} \\
(0.000)\end{array}$ & & \\
\hline REMITTANCES $\times M 2$ & $\begin{array}{c}-0.007^{*} \\
(0.004)\end{array}$ & $\begin{array}{c}-0.014 * * * \\
(0.005)\end{array}$ & & \\
\hline CREDIT & & & $\begin{array}{l}0.001 * \\
(0.000)\end{array}$ & $\begin{array}{c}0.001 \\
(0.001)\end{array}$ \\
\hline REMITTANCES $\times$ & & & -0.006 & $-0.010^{* *}$ \\
\hline CREDIT & & & $(0.004)$ & $(0.005)$ \\
\hline No. obs. & 233 & 233 & 233 & 233 \\
\hline No. countries & 62 & 62 & 62 & 62 \\
\hline $\operatorname{AR}(1)$ test & & 0.01 & & 0.01 \\
\hline $\operatorname{AR}(2)$ test & & 0.18 & & 0.22 \\
\hline Hansen test & & 0.67 & & 0.73 \\
\hline
\end{tabular}

Note: Level of significance: ${ }^{*} 0.10$; ${ }^{* *} 0.05 ;{ }^{* * *} 0.01$. Robust S.E. in parentheses. P-values for first and second order autocorrelation and for the Hansen test are reported. 
TABLE 4

Estimations with quality- and quantity-based indicators for financial development

\begin{tabular}{|c|c|c|c|c|c|c|c|c|}
\hline \multirow{2}{*}{ Dep Var: GDP growth } & \multicolumn{4}{|c|}{ Fiveyear averages } & \multicolumn{4}{|c|}{ Annual data } \\
\hline & OLS & SGMM & SGMM & SGMM & OLS & SGMM & SGMM & SGMM \\
\hline$G D P_{t-1}$ & $\begin{array}{c}-0.023 * * \\
(0.009)\end{array}$ & $\begin{array}{c}-0.062^{*} \\
(0.035)\end{array}$ & $\begin{array}{c}-0.067^{*} \\
(0.039)\end{array}$ & $\begin{array}{l}-0.079 \\
(0.061)\end{array}$ & $\begin{array}{l}-0.005^{* * *} \\
(0.002)\end{array}$ & $\begin{array}{c}-0.049 * * * \\
(0.018)\end{array}$ & $\begin{array}{c}-0.049 * * \\
(0.019)\end{array}$ & $\begin{array}{c}-0.048^{* * *} \\
(0.017)\end{array}$ \\
\hline POPULATION GROWTH & $\begin{array}{c}-0.054 * * * \\
(0.012)\end{array}$ & $\begin{array}{c}-0.076 * * * \\
(0.024)\end{array}$ & $\begin{array}{c}-0.074 * * * \\
(0.023)\end{array}$ & $\begin{array}{c}-0.079 * * * \\
(0.023)\end{array}$ & $\begin{array}{c}-0.012 * * * \\
(0.002)\end{array}$ & $\begin{array}{c}-0.020 * * * \\
(0.007)\end{array}$ & $\begin{array}{c}-0.020^{* * *} \\
(0.007)\end{array}$ & $\begin{array}{c}-0.020^{* * *} \\
(0.007)\end{array}$ \\
\hline INVESTMENTS & $\begin{array}{c}0.144 * * * \\
(0.040)\end{array}$ & $\begin{array}{c}0.145^{* * *} \\
(0.049)\end{array}$ & $\begin{array}{c}0.135^{* * *} \\
(0.050)\end{array}$ & $\begin{array}{c}0.110^{* *} \\
(0.047)\end{array}$ & $\begin{array}{c}0.021 * * * \\
(0.001)\end{array}$ & $\begin{array}{c}0.041 * * \\
(0.018)\end{array}$ & $\begin{array}{l}0.033^{*} \\
(0.017)\end{array}$ & $\begin{array}{c}0.039 * * \\
(0.018)\end{array}$ \\
\hline INFLATION & $\begin{array}{l}-0.001 \\
(0.001)\end{array}$ & $\begin{array}{c}0.000 \\
(0.001)\end{array}$ & $\begin{array}{c}0.000 \\
(0.001)\end{array}$ & $\begin{array}{c}0.001 \\
(0.001)\end{array}$ & $\begin{array}{c}-0.001 * * * \\
(0.000)\end{array}$ & $\begin{array}{c}0.000 \\
(0.000)\end{array}$ & $\begin{array}{c}0.000 \\
(0.000)\end{array}$ & $\begin{array}{c}0.000 \\
(0.000)\end{array}$ \\
\hline $\begin{array}{l}\text { GOVERNMENT } \\
\text { EXPENDITURES }\end{array}$ & $\begin{array}{c}-0.004 * * \\
(0.002)\end{array}$ & $\begin{array}{l}-0.003 \\
(0.003)\end{array}$ & $\begin{array}{l}-0.004 \\
(0.003)\end{array}$ & $\begin{array}{l}-0.004 \\
(0.004)\end{array}$ & $\begin{array}{c}-0.001 * * * \\
(0.000)\end{array}$ & $\begin{array}{c}0.000 \\
(0.000)\end{array}$ & $\begin{array}{c}0.000 \\
(0.001)\end{array}$ & $\begin{array}{c}0.000 \\
(0.001)\end{array}$ \\
\hline $\begin{array}{l}\text { OPENNESS } \\
\text { M2 }\end{array}$ & $\begin{array}{c}0.020 \\
(0.019)\end{array}$ & $\begin{array}{c}0.024 \\
(0.030)\end{array}$ & $\begin{array}{c}0.023 \\
(0.029) \\
0.001 \\
(0.001)\end{array}$ & $\begin{array}{c}0.012 \\
(0.045)\end{array}$ & $\begin{array}{l}-0.001 \\
(0.002)\end{array}$ & $\begin{array}{l}0.027^{*} \\
(0.016)\end{array}$ & $\begin{array}{c}0.021 \\
(0.014) \\
0.0003^{*} \\
(0.000)\end{array}$ & $\begin{array}{c}0.023 \\
(0.014)\end{array}$ \\
\hline CREDIT & & & & $\begin{array}{c}0.001 \\
(0.001)\end{array}$ & & & & $\begin{array}{c}0.000 \\
(0.000)\end{array}$ \\
\hline REMITTANCES & $\begin{array}{l}0.060^{*} \\
(0.035)\end{array}$ & $\begin{array}{c}0.247 * * * \\
(0.075)\end{array}$ & $\begin{array}{c}0.232^{* * *} \\
(0.068)\end{array}$ & $\begin{array}{c}0.273^{* *} \\
(0.107)\end{array}$ & $\begin{array}{c}0.002 \\
(0.013)\end{array}$ & $\begin{array}{c}0.230^{* *} \\
(0.106)\end{array}$ & $\begin{array}{c}0.217 * * \\
(0.106)\end{array}$ & $\begin{array}{c}0.228^{* *} \\
(0.102)\end{array}$ \\
\hline$B A N K$ INEFFICIENCY & $\begin{array}{l}-0.055 \\
(0.040)\end{array}$ & $\begin{array}{c}-0.283 * * * \\
(0.010)\end{array}$ & $\begin{array}{c}-0.256 * * * \\
(0.090)\end{array}$ & $\begin{array}{c}-0.321 * * * \\
(0.124)\end{array}$ & $\begin{array}{l}-0.006 \\
(0.014)\end{array}$ & $\begin{array}{c}-0.214 * * \\
(0.107)\end{array}$ & $\begin{array}{l}-0.198^{*} \\
(0.107)\end{array}$ & $\begin{array}{c}-0.214^{* *} \\
(0.104)\end{array}$ \\
\hline $\begin{array}{l}\text { REMITTANCES } \times \\
B A N K \text { INEFFICIENCY }\end{array}$ & $\begin{array}{c}-0.014^{*} \\
(0.008)\end{array}$ & $\begin{array}{l}-0.056 * * * \\
(0.018)\end{array}$ & $\begin{array}{c}-0.054 * * * \\
(0.016)\end{array}$ & $\begin{array}{c}-0.062 * * \\
(0.024)\end{array}$ & $\begin{array}{l}-0.001 \\
(0.003)\end{array}$ & $\begin{array}{l}-0.058^{*} \\
(0.026)\end{array}$ & $\begin{array}{c}-0.055^{* *} \\
(0.026)\end{array}$ & $\begin{array}{c}-0.058^{* *} \\
(0.025)\end{array}$ \\
\hline No. obs. & 153 & 153 & 153 & 153 & 618 & 618 & 617 & 616 \\
\hline No. countries & 63 & 63 & 63 & 63 & 66 & 66 & 66 & 66 \\
\hline $\operatorname{AR}(1)$ test & & 0.98 & 0.91 & 0.69 & & 0.00 & 0.00 & 0.00 \\
\hline $\operatorname{AR}(2)$ test & & & & & & 0.35 & 0.36 & 0.33 \\
\hline Hansen test & & 0.59 & 0.56 & 0.77 & & 0.60 & 0.43 & 0.63 \\
\hline
\end{tabular}

Note: Level of significance: * 0.10 ; ** 0.05 ; *** 0.01. Robust S.E. in parentheses. P-values for first and second order autocorrelation and for the Hansen test are reported. 
TABLE 5

Estimations with quality-based indicator for financial development and governance indicators

\begin{tabular}{|c|c|c|c|c|c|c|c|c|c|c|c|}
\hline Dep Var: GDP growth & SGMM & SGMM & SGMM & SGMM & SGMM & SGMM & SGMM & SGMM & SGMM & SGMM & SGMM \\
\hline$G D P_{t-1}$ & $\begin{array}{c}-0.026 * * * \\
(0.007)\end{array}$ & $\begin{array}{c}-0.023^{* * *} \\
(0.009)\end{array}$ & $\begin{array}{c}-0.026 * * * \\
(0.008)\end{array}$ & $\begin{array}{c}-0.020 * * * \\
(0.007)\end{array}$ & $\begin{array}{c}-0.023 * * * \\
(0.008)\end{array}$ & $\begin{array}{c}-0.026 * * * \\
(0.007)\end{array}$ & $\begin{array}{c}-0.025^{* * *} \\
(0.007)\end{array}$ & $\begin{array}{c}-0.036 * * * \\
(0.008)\end{array}$ & $\begin{array}{c}-0.044^{* *} \\
(0.020)\end{array}$ & $\begin{array}{c}-0.032^{* *} \\
(0.015)\end{array}$ & $\begin{array}{c}-0.042^{* * *} \\
(0.012)\end{array}$ \\
\hline POPULATION GROWTH & $\begin{array}{c}-0.019 * * * \\
(0.004)\end{array}$ & $\begin{array}{c}-0.019 * * * \\
(0.005)\end{array}$ & $\begin{array}{c}-0.019 * * * \\
(0.004)\end{array}$ & $\begin{array}{c}-0.019 * * * \\
(0.005)\end{array}$ & $\begin{array}{c}-0.019 * * * \\
(0.004)\end{array}$ & $\begin{array}{c}-0.017^{* * *} \\
(0.004)\end{array}$ & $\begin{array}{c}-0.016^{* * *} \\
(0.004)\end{array}$ & $\begin{array}{c}-0.016^{* * *} \\
(0.005)\end{array}$ & $\begin{array}{c}-0.021 * * * \\
(0.008)\end{array}$ & $\begin{array}{c}-0.016^{* *} \\
(0.006)\end{array}$ & $\begin{array}{c}-0.017 * * * \\
(0.005)\end{array}$ \\
\hline INVESTMENTS & $\begin{array}{c}0.017^{*} \\
(0.010)\end{array}$ & $\begin{array}{c}0.02 \\
(0.013)\end{array}$ & $\begin{array}{c}0.017 \\
(0.011)\end{array}$ & $\begin{array}{c}0.012 \\
-0.01\end{array}$ & $\begin{array}{l}0.020^{*} \\
(0.011)\end{array}$ & $\begin{array}{c}0.016 \\
-0.01\end{array}$ & $\begin{array}{c}0.015 \\
(0.010)\end{array}$ & $\begin{array}{l}0.022^{*} \\
(0.011)\end{array}$ & $\begin{array}{c}0.021 \\
(0.023)\end{array}$ & $\begin{array}{l}0.026^{*} \\
(0.016)\end{array}$ & $\begin{array}{c}0.02 \\
(0.018)\end{array}$ \\
\hline INFLATION & $\begin{array}{l}-0.001 \\
(0.000)\end{array}$ & $\begin{array}{l}-0.001 \\
(0.000)\end{array}$ & $\begin{array}{l}-0.001 \\
(0.000)\end{array}$ & $\begin{array}{l}-0.000 \\
(0.000)\end{array}$ & $\begin{array}{l}-0.000 \\
(0.000)\end{array}$ & $\begin{array}{l}-0.000 \\
(0.000)\end{array}$ & $\begin{array}{l}-0.000 \\
(0.000)\end{array}$ & $\begin{array}{l}0.000 \\
(0.000)\end{array}$ & $\begin{array}{l}-0.000 \\
(0.000)\end{array}$ & $\begin{array}{l}-0.000 \\
(0.000)\end{array}$ & $\begin{array}{l}0.000 \\
(0.000)\end{array}$ \\
\hline GOVERNMENT EXPENDITURES & $\begin{array}{l}-0.001 * \\
(0.000)\end{array}$ & $\begin{array}{l}-0.001 \\
(0.001)\end{array}$ & $\begin{array}{l}-0.001 \\
(0.001)\end{array}$ & $\begin{array}{l}-0.001 \\
(0.001)\end{array}$ & $\begin{array}{l}-0.001 \\
(0.001)\end{array}$ & $\begin{array}{l}-0.001 \\
(0.001)\end{array}$ & $\begin{array}{l}-0.001 * \\
(0.000)\end{array}$ & $\begin{array}{c}-0.0001 \\
(0.001)\end{array}$ & $\begin{array}{l}-0.001 \\
(0.001)\end{array}$ & $\begin{array}{l}-0.001 \\
(0.001)\end{array}$ & $\begin{array}{l}-0.001 \\
(0.001)\end{array}$ \\
\hline OPENNESS & $\begin{array}{c}0.003 \\
(0.005)\end{array}$ & $\begin{array}{c}0.004 \\
(0.006)\end{array}$ & $\begin{array}{c}0.001 \\
(0.006)\end{array}$ & $\begin{array}{c}0.001 \\
(0.006)\end{array}$ & $\begin{array}{c}0.007 \\
(0.006)\end{array}$ & $\begin{array}{c}0.002 \\
(0.005)\end{array}$ & $\begin{array}{c}0.003 \\
(0.005)\end{array}$ & $\begin{array}{c}0.015^{* *} \\
(0.007)\end{array}$ & $\begin{array}{c}0.022 \\
(0.015)\end{array}$ & $\begin{array}{c}0.004 \\
(0.009)\end{array}$ & $\begin{array}{c}0.009 \\
(0.009)\end{array}$ \\
\hline REMITTANCES & $\begin{array}{c}0.113^{* * *} \\
(0.030)\end{array}$ & $\begin{array}{c}0.127^{* * *} \\
(0.032)\end{array}$ & $\begin{array}{c}0.103^{* * *} \\
(0.032)\end{array}$ & $\begin{array}{c}0.107^{* * *} \\
(0.030)\end{array}$ & $\begin{array}{c}0.116^{* * *} \\
(0.033)\end{array}$ & $\begin{array}{c}0.097 * * * \\
(0.033)\end{array}$ & $\begin{array}{c}0.113^{* * *} \\
(0.043)\end{array}$ & $\begin{array}{c}0.180^{* * *} \\
(0.046)\end{array}$ & $\begin{array}{l}0.160^{*} \\
(0.095)\end{array}$ & $\begin{array}{l}0.147^{*} \\
(0.086)\end{array}$ & $\begin{array}{c}0.206^{* *} \\
(0.095)\end{array}$ \\
\hline BANK INEFFICIENCY & $\begin{array}{c}-0.110^{* * *} \\
(0.034)\end{array}$ & $\begin{array}{c}-0.133^{* * *} \\
(0.037)\end{array}$ & $\begin{array}{c}-0.098^{* * *} \\
(0.035)\end{array}$ & $\begin{array}{c}-0.112^{* * *} \\
(0.034)\end{array}$ & $\begin{array}{c}-0.120^{* * *} \\
(0.038)\end{array}$ & $\begin{array}{c}-0.096^{* *} \\
(0.038)\end{array}$ & $\begin{array}{c}-0.117 * * \\
(0.046)\end{array}$ & $\begin{array}{c}-0.120^{* *} \\
(0.048)\end{array}$ & $\begin{array}{c}-0.157 * * \\
(0.079)\end{array}$ & $\begin{array}{l}-0.139 * \\
(0.080)\end{array}$ & $\begin{array}{c}-0.180^{* *} \\
(0.084)\end{array}$ \\
\hline REMITTANCES $\times B$ ANK INNEFICIENCY & $\begin{array}{c}-0.028 * * * \\
(0.007)\end{array}$ & $\begin{array}{c}-0.032^{* * *} \\
(0.008)\end{array}$ & $\begin{array}{c}-0.026^{* * *} \\
(0.008)\end{array}$ & $\begin{array}{c}-0.027 * * * \\
(0.007)\end{array}$ & $\begin{array}{c}-0.029 * * * \\
(0.008)\end{array}$ & $\begin{array}{c}-0.024 * * * \\
(0.008)\end{array}$ & $\begin{array}{c}-0.028^{* * *} \\
(0.011)\end{array}$ & $\begin{array}{c}-0.034 * * * \\
(0.011)\end{array}$ & $\begin{array}{c}-0.042^{* *} \\
(0.018)\end{array}$ & $\begin{array}{c}-0.037^{*} \\
(0.019)\end{array}$ & $\begin{array}{c}-0.047^{* *} \\
(0.021)\end{array}$ \\
\hline CONTROL OF CORRUPTION & $\begin{array}{c}0.045^{* * *} \\
(0.010)\end{array}$ & & & & & & $\begin{array}{c}0.023 \\
(0.027)\end{array}$ & & & & \\
\hline REMITTANCES*CONTROL OF CORRUP. & $\begin{array}{c}0.005^{* * *} \\
(0.001)\end{array}$ & & & & & & $\begin{array}{c}0.005 \\
(0.006)\end{array}$ & & & & \\
\hline REGULATORY QUALITY & & $\begin{array}{c}0.049 * * * \\
(0.014)\end{array}$ & & & & & $\begin{array}{c}0.042^{* *} \\
(0.018)\end{array}$ & & & & \\
\hline REMITTANCES*REGULATORY QUALITY & & $\begin{array}{c}0.006^{* * *} \\
(0.002)\end{array}$ & & & & & $\begin{array}{c}0.010^{* *} \\
(0.004)\end{array}$ & & & & \\
\hline RULE OF LAW & & & $\begin{array}{c}0.036^{* * *} \\
(0.009)\end{array}$ & & & & $\begin{array}{l}-0.001 \\
(0.036)\end{array}$ & & & & \\
\hline REMITTANCES*RULE OF LAW & & & $\begin{array}{c}0.003 * * \\
(0.002)\end{array}$ & & & & $\begin{array}{c}0.001 \\
(0.001)\end{array}$ & & & & \\
\hline
\end{tabular}




\begin{tabular}{|c|c|c|c|c|c|c|c|c|c|c|c|}
\hline POLITICAL STABILITY & & & & $\begin{array}{c}0.009 \\
0.008\end{array}$ & & & & & & & \\
\hline REMITTANCES*POLITICAL STABILITY & & & & $\begin{array}{c}0.001 \\
(0.001)\end{array}$ & & & & & & & \\
\hline VOICE AND ACCOUNTABILITY & & & & & $\begin{array}{l}-0.000 \\
(0.010)\end{array}$ & & & & & & \\
\hline REMITTANCES*VOICE AND ACCOUNT. & & & & & $\begin{array}{l}-0.001 \\
(0.002)\end{array}$ & & & & & & \\
\hline GOVERNMENT EFFICIENCY & & & & & & $\begin{array}{c}0.038^{* * *} \\
(0.008)\end{array}$ & $\begin{array}{l}-0.014 \\
(0.022)\end{array}$ & & & & \\
\hline REMITTANCES*GOVERNMENT EFFIC. & & & & & & $\begin{array}{c}0.002 \\
(0.002)\end{array}$ & $\begin{array}{c}-0.011 \\
(0.008)\end{array}$ & & & & \\
\hline ECONOMIC RISK RATING & & & & & & & & $\begin{array}{l}-0.001 \\
(0.003)\end{array}$ & & & \\
\hline REMITTANCES* ECONOMIC R.R. & & & & & & & & $\begin{array}{c}-0.001^{* *} \\
(0.001)\end{array}$ & & & \\
\hline FINANCLAL RISK RATING & & & & & & & & & $\begin{array}{c}0.004 \\
(0.003)\end{array}$ & & \\
\hline REMITTANCES* FINANCLAL R.R. & & & & & & & & & $\begin{array}{c}0.000 \\
(0.001)\end{array}$ & & \\
\hline POLITICAL RISK RATING & & & & & & & & & \multicolumn{3}{|c|}{$\begin{array}{c}0.002 \\
(0.002)\end{array}$} \\
\hline REMITTANCES* POLITICAL R.R. & & & & & & & & & \multicolumn{3}{|c|}{$\begin{array}{c}0.000 \\
(0.000)\end{array}$} \\
\hline COMPOSITE RISK INDEX & & & & & & & & & & & $\begin{array}{c}0.002 \\
(0.002)\end{array}$ \\
\hline REMITTANCES* COMPOSITE R.I. & & & & & & & & & & & $\begin{array}{l}-0.000 \\
(0.001)\end{array}$ \\
\hline No. obs. & 355 & 358 & 357 & 348 & 358 & 358 & 355 & 497 & 497 & 497 & 497 \\
\hline No. countries & 64 & 64 & 64 & 64 & 64 & 64 & 64 & 57 & 57 & 57 & 57 \\
\hline $\operatorname{AR}(1)$ test & 0.02 & 0.02 & 0.02 & 0.03 & 0.03 & 0.03 & 0.04 & 0.00 & 0.00 & 0.00 & 0.00 \\
\hline $\operatorname{AR}(2)$ test & 0.21 & 0.19 & 0.18 & 0.20 & 0.19 & 0.25 & 0.60 & 0.57 & 0.61 & 0.28 & 0.66 \\
\hline Hansen test & 0.17 & 0.18 & 0.22 & 0.07 & 0.13 & 0.32 & 0.27 & 0.69 & 0.32 & 0.44 & 0.49 \\
\hline
\end{tabular}

